\title{
Tsunami Risk Evaluation Based on Land Suitability for Settlement in Pacitan Coastal Area, East Java
}

\author{
Djati Mardiatno \\ Faculty of Geography \\ Universitas Gadjah Mada \\ Bulaksumur, Yogyakarta \\ Coresponding email: djati.mardiatno@ugm.ac.id \\ Cintya Wahyu Permatasari \\ Faculty of Geography \\ Universitas Gadjah Mada \\ Bulaksumur Yogyakarta \\ Mukhamad Ngainul Malawani \\ MPPDAS-Faculty of Geography \\ Universitas Gadjah Mada \\ Bulaksumur, Yogyakarta \\ Fitria Nuraini Sekarsih \\ Research Center for Disasters (PSBA) \\ Universities Gadjah Mada \\ Jl. Mahoni C-16, Bulaksumur, Yogyakarta
}

\begin{abstract}
The aims of this research are to determine the changes of tsunami risk in coastal area of Pacitan and to evaluate it by considering land suitability for settlement. Comparative method was used to analyse between existing risk from land use map and potential risk from land suitability for settlement map. These comparison also considered the regional spatial plan of Pacitan Sub-district. Tsunami hazard map was taken from previous research to build the tsunami risk scenario. Tsunami hazard could be classified into five level, i.e. very low, low, medium, high, and very high. Based on this model, the research area is dominated by very high level of tsunami hazard. The results showed that Pacitan Sub-district has land suitability for settlement at the moderate level (S2) and not suitable (S3) level. Land suitability with level S2 is highly potential for settlement development that might result in tsunami risk change. Refer to the risk analysis result, it can be seen that actual and potential element at risk is going up between 2014 and 2034. The actual increase is about $123 \mathrm{Ha}$ while and potential increase is about $1.342 \mathrm{Ha}$. If there is no control at developing of settlement, there are very wide area of settlement development will be built in the high level of tsunami hazard area. As consequence, the risk of the tsunami will be higher as well.
\end{abstract}

Keywords-Tsunami hazard, element at risk, land suitability, settlement, risk evaluation.

\section{INTRODUCTION}

Indonesia is geographically located on the collision of three active tectonic plates in the world, namely the Eurasian plate, the India-Australian plate and the Pacific plate. As a consequence, this country is very prone to earthquakes and tsunamis. Based on the tsunami vulnerable area map released by Geospatial Information Agency (BIG, previously Bakosurtanal), most of the coastal areas in Indonesia is prone to tsunamis.

Tsunami in Indonesia has special characteristics, where the travel time from the source is relatively short (Mardiatno 2008; Muhari et al, 2012). The average travel time in Indonesia's tsunami waves reach the shoreline of no more than 1 hour. The tsunami waves in Banyuwangi (1994) takes about 40 minutes to reach the shoreline and was not preceded by receding sea level. The tsunami waves in Aceh (2004) reached the shoreline in about 30 minutes. The tsunami in Pangandaran takes about 20 minutes to reach the shoreline. According to this reality, the tsunami disaster mitigation efforts should also be planned properly.

Indian Ocean tsunami in 2004 struck most coastal area of Aceh Province, which seized the attention of the whole society level in Indonesia even around the world. Lack of preparedness and awareness of the tsunami disaster and lack response to the tsunami risk at that time resulted in huge losses. After tsunami disaster, many types of research were carried out focusing on tsunami risk, especially in the several areas prone to tsunami hazard. It is directed to improve the preparedness and awareness, especially for reducing the tsunami risk. Many 
researches related to tsunami has been done in Padang, Bali, Palu, Cilacap, and Pacitan (Mardiatno, Djati 2008); (Taubenbock, $\mathrm{H}$ et all,); (United Nations International Strategy for Disaster R'eduction, 2009); (Harspool, N et all, 2014); (Muta'ali, Lutfi 2015).

Tsunami research in Pacitan conducted by Mardiatno (2008) has been done by creating models of tsunami affected areas based on the worst case scenario of tsunami hazard. In the context of development, the disaster mapping such as tsunami hazard mapping is one important things for spatial planning (Pawlukiewicz, Michael et all, 2007). Spatial planning framework based on disaster potential is one of risk reduction strategy by long-term planning to develop settlement area or another built up area. (Strunz, G et all); (Lassey, W.R 2007). This built up area is a form of physical vulnerability, so it requires an effective and efficient planning for settlement (United Nations International Strategy for Disaster R'eduction, 2009); (Cinacher, A.J and Conacher, J, 2000)

Pacitan is a region which has various landforms. This region also has various disaster potential; one of them is tsunami. The main city area is located in relatively flat topography at the coastal area and it is also surrounded by hilly topography. This condition triggers a certain challenge for spatial planning, since almost the entire city of Pacitan is susceptible to tsunami (Mardiatno, Djati, 2008). Moreover, the population increases every year and result in diverse economic activity. It would be in line with settlements and other built up area development (Baja, Sumbangan, 2012); (Muta'ali, Lutfi., 2015). This research aims to determine the changes of tsunami risk in coastal area of Pacitan and to evaluate that change based on land suitability for settlement.

The physical condition (landscape) of a certain area can be used as an approach for spatial planning through land suitability evaluation process (Hardjowigeno, S. dan Widiatmaka, 2007) Land suitability evaluation is required to determine the various alternative land use (Brinkman, R, dan A.J. Smith, 1973); (FAO, 1976). Basically, the physical condition (landscape), disaster management, spatial planning with land evaluation are used on the comprehensive assessment of regional spatial planning (Pawlukiewicz, Michael, et all, 2007), especially in dynamic coastal area like in Pacitan.

\section{METHOD}

This research used primary data and secondary data. Primary data were obtained mainly from field observation result. Primary data includes landform parameter, present land use, interview results from selected respondents, and field photographs. As for secondary data were obtained from the results of previous studies and data from relevant institutions or agencies, i.e.: Topographic Map of Indonesia scale 1: 25,000, geomorphology map, tsunami hazard map, land use maps, images from Google Earth (2004, 2006, 20014), settlement planning map (from RDTRK), and sub-districts in figures

Tools and materials used in this research were GPS (Global Positioning System), a digital camera, a computer for data processing, voice recorder, field measuring instruments (geological compass, measurement stand, laser distance meter, and clinometer), checklists, and interview guides. Samples were collected by using stratified sampling techniques, where the level of tsunami hazard was functioned as the strata. Three phases of analysis conducted in this research can be explained as follows.

- Analysis of existing land use change and growth, especially the development of extensive residential areas. This analysis was done by comparing the temporal land use.

- Analysis of population growth. This analysis is used to determine the relationship between population growths with land use changes.

- Analysis and evaluation of tsunami risk level changes. At this phase, the exisitng tsunami risk level will be compared with the risk level of tsunami in the future. This analysis was limited to the elements at risk, particularly the settlement area.

\section{FINDING AND DISCUSSION}

Population growth is one important factor which is used in land use planning consideration. The land planning for settlement development was conducted by using the number of household projection, which assumed that one household lived in one house. The increase number of household from projected result were assumed as the number of house. Based on the statistical data, the number of household in district of Pacitan is 16.053 in 2004 and 21.289 in 2014. The household growth from 2004 to 2014 is $2,80 \%$, which can be classified as moderate growth. By this calculation, there will be the growing number of households amounted to 27.445 households in 2034. That means, by the year of 2034, there will be 27.445 houses added in the district of Pacitan. Meanwhile, if calculated from year 2012 to 2034, there were 22.926 additional houses in the district of Pacitan (TABLE I). By calculation the area needed for housing and household projection based on minimum land area requirement for houses, the area need for new housing can be obtained. Based on the government regulation number 11/PERMEN/M/2008, the minimum area for the middle-sized house is $54 \mathrm{~m}^{2}$ to $600 \mathrm{~m} 2$.

TABLE I. LAND REQUIREMENT FOR HOUSING IN PACITAN SUBDISTRICT

\begin{tabular}{|l|r|r|r|r|r|}
\hline \multicolumn{1}{|c|}{ Village } & \multicolumn{1}{|c|}{2012} & \multicolumn{1}{c|}{2034} & Change & \multicolumn{1}{c|}{$\begin{array}{c}\text { House } \\
\text { Need } \\
\left(\mathrm{m}^{2}\right)\end{array}$} & \multicolumn{1}{c|}{$\begin{array}{c}\text { Land } \\
\text { Need } \\
\text { (ha) }\end{array}$} \\
\hline Sumberharjo & 446 & 1115 & 669 & 36140 & 3,61 \\
\hline Sedeng & 876 & 2172 & 1296 & 69973 & 7,00 \\
\hline Pacitan & 964 & 1213 & 249 & 13452 & 1,35 \\
\hline Ploso & 1748 & 4257 & 2509 & 135467 & 13,55 \\
\hline Sidoharjo & 2151 & 7460 & 5309 & 286682 & 28,67 \\
\hline Tanjungsari & 1150 & 1683 & 533 & 28798 & 2,88 \\
\hline Semanten & 487 & 745 & 258 & 13957 & 1,40 \\
\hline Baleharjo & 889 & 1363 & 474 & 25620 & 2,56 \\
\hline Bangunsari & 1251 & 2381 & 1130 & 61034 & 6,10 \\
\hline Ponggok & 605 & 1002 & 397 & 21426 & 2,14 \\
\hline
\end{tabular}




\begin{tabular}{|c|c|c|c|c|c|}
\hline Village & 2012 & 2034 & Change & $\begin{array}{c}\text { House } \\
\text { Need } \\
\left(\mathrm{m}^{2}\right)\end{array}$ & $\begin{array}{l}\text { Land } \\
\text { Need } \\
\text { (ha) }\end{array}$ \\
\hline Banjarsari & 402 & 422 & 20 & 1067 & 0,11 \\
\hline Purworejo & 507 & 711 & 204 & 11041 & 1,10 \\
\hline Tambakrejo & 600 & 921 & 321 & 17353 & 1,74 \\
\hline Sirnoboyo & 1271 & 1817 & 546 & 29506 & 2,95 \\
\hline Nanggungan & 639 & 939 & 300 & 16214 & 1,62 \\
\hline Kembang & 687 & 913 & 226 & 12184 & 1,22 \\
\hline Mentoro & 752 & 1884 & 1132 & 61132 & 6,11 \\
\hline Sukoharjo & 447 & 697 & 250 & 13489 & 1,35 \\
\hline Kayen & 791 & 1716 & 925 & 49954 & 5,00 \\
\hline Sambong & 945 & 5575 & 4630 & 250000 & 25,00 \\
\hline Pucangsewu & 939 & 1131 & 192 & 10391 & 1,04 \\
\hline Arjowinangun & 857 & 1090 & 233 & 12581 & 1,26 \\
\hline Bolosingo & 422 & 123 & 0 & 0 & 0,00 \\
\hline Widoro & 513 & 815 & 302 & 16299 & 1,63 \\
\hline Menadi & 532 & 1351 & 819 & 44248 & 4,42 \\
\hline TOTAL & 20871 & 43498 & 22926 & 1238007 & 123,80 \\
\hline
\end{tabular}

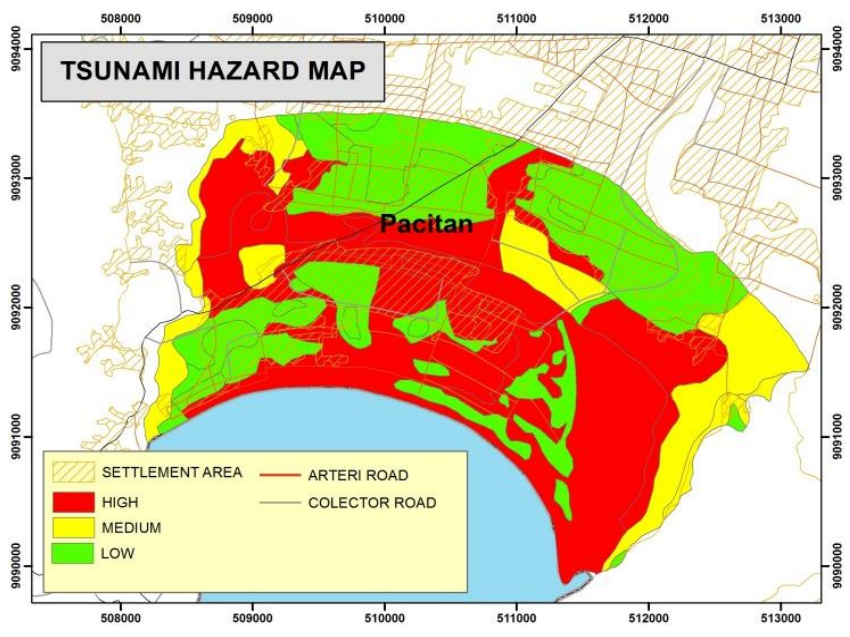

Fig. 1. Tsunami Hazard Map of Pacitan Sub-District

To evaluate the tsunami risk, it is necessary to select one of the elements at risk. In this research, settlement areas were chosen as the element at risk. The reason in selecting settlement as element at risk is based on the reality that built up area or settlements change rapidly comparing to others. The evaluation on tsunami risk change refers to the comparison between tsunami impact on existing land use (2014) and impact on the land use planning in 2034. These changes can be analyzed by overlay tsunami hazard map and settlement map in 2014 and 2034. The result is shown in TABLE II.

TABLE II. Comparison Settlement Area of Tsunami Impact In Pacitan susceptible to tsunami. This area is located adjacent to the subduction zone in the Indian Ocean, one of the potential sources for tsunami. The coastal area is also characterized by a gulf morphology. Indonesia National Disaster Management Authority (BNPB) also classified Pacitan as a district which has a high risk to tsunami. The potential for inundation (flowdepth) by the tsunami in Pacitan districts can reach $10,8 \mathrm{~m}$, with an average of flooding is $4 \mathrm{~m}$. As for the propagation speed of the flow is $14,59 \mathrm{~m} / \mathrm{sec}$ maximum, with the average speed is 3,6 $\mathrm{m} / \mathrm{sec}$ (Muhari, A., 2012). Refer to these results, the potential danger of a tsunami in the region were high.

The results for tsunami hazard modeling was classified into three classes, i.e. high, medium, and low. These results refer to the previous model by Mardiatno (2008). The simulation was done in a various scenarios. Earthquake from sea floor were simulated by using the following earthquake magnitude $(\mathrm{Mw})$ 7.5; 8.0; and 8.5. Hypothetic location of epicenter was determined at the coordinate as follow: $111.0^{\circ} \mathrm{E} ;-9.5^{\circ} \mathrm{S}$. The simulation results were used as material for relationship analysis between tsunami hazard distribution and settlement growth. Tsunami hazard map is shown in Figure 1.

\begin{tabular}{|l|r|r|}
\hline Tsunami Hazard Level & $\begin{array}{r}\text { Affected Area (Ha) } \\
\mathbf{2 0 1 4}\end{array}$ & $\begin{array}{c}\text { Affected Area (Ha) } \\
\mathbf{2 0 3 4}\end{array}$ \\
\hline Low & 229,744 & 350,064 \\
\hline Medium & 132,412 & 180,729 \\
\hline High & 93,394 & 355,392 \\
\hline Total & 455,550 & 886,185 \\
\hline
\end{tabular}

The development of settlements in 2034 led to the increase of elements at risk in each class of tsunami hazard. The area affected by high level of tsunami hazard is dominant in this research area. Refer to this trend, the development of settlements is projected to be area within high class of tsunami hazard. By the total of affected area, from 2014 to 2034 showed that area increase nearly doubled as much. This condition is similar to the increase of household number. The comparison between tsunami impact map on the elements at risk in 2014 and 2034 can be seen in Figure 2 and Figure 3. 


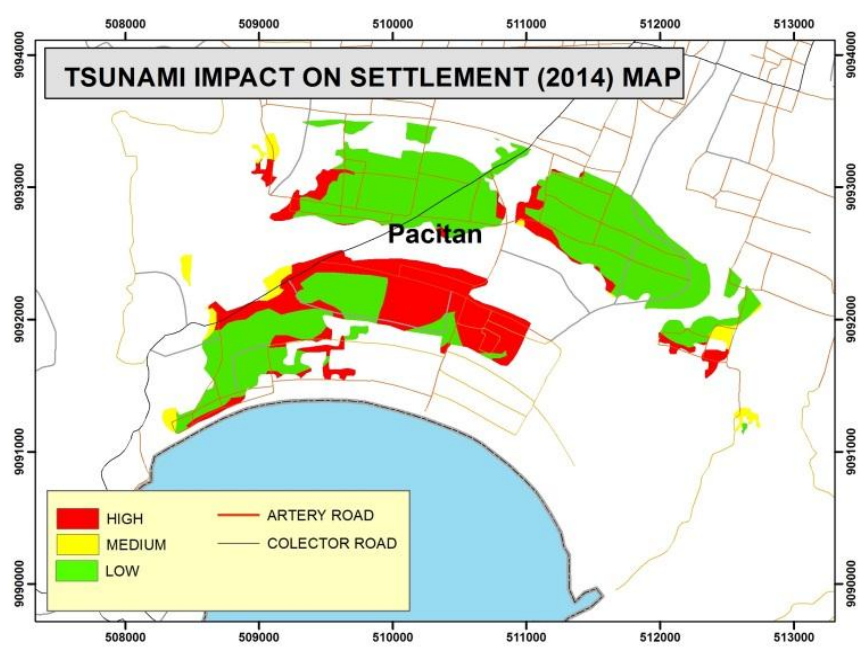

Fig. 2. Tsunami Impact on Settlement Map (2014)

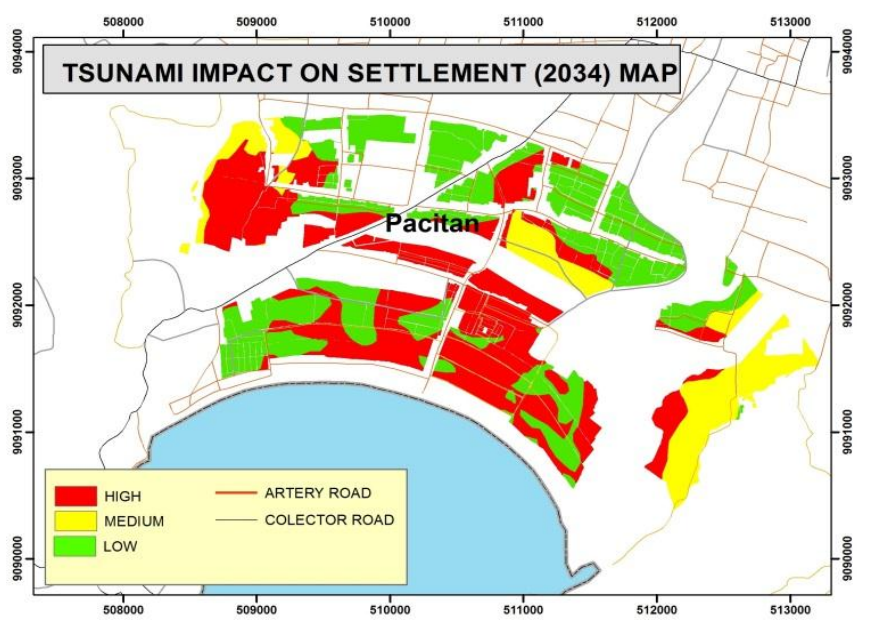

Fig. 3. Tsunami Impact on Settlement Map (2034)

Based on simulation results in the future, it would require some action to reduce the tsunami risk. Regulation on settlement growth might be done by allocating the new settlements to the area suitable for housing. According to the mapping results, the population growth can be allocated to land which has moderate or high land suitability class. By using this strategy, the risk to tsunami in the future can be reduced. Through comparing the settlements growth and land suitability, risk evaluation changes can be carried out as well. Figure 4 shows the results of risk evaluation to settlement growth in Pacitan. It can be seen that some settlements are located in the medium suitability, while the rest is in the low suitability. This distribution can be used for more analysis related to the tsunami risk potential in that area.

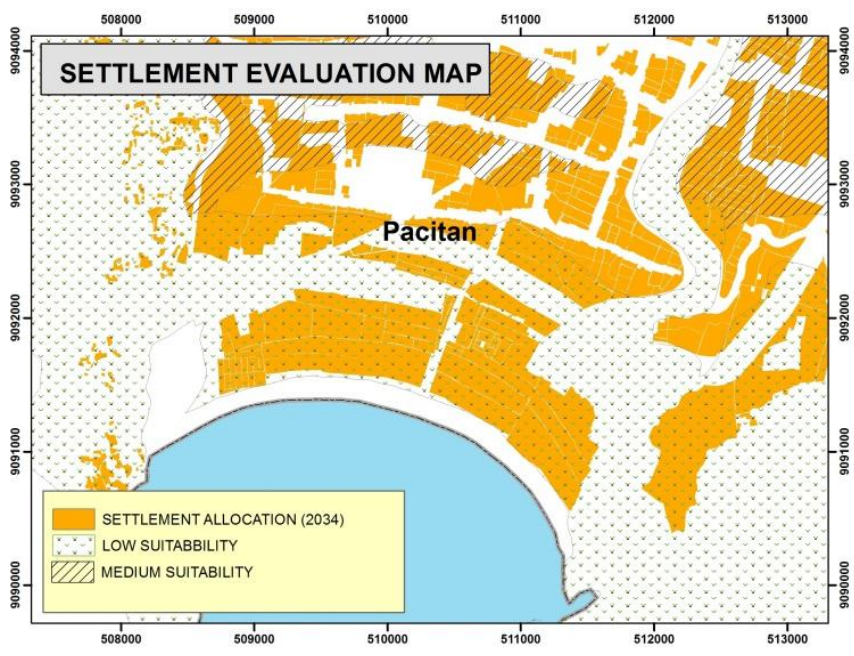

Fig. 4. Settlement Evaluation Based on Land Suitability Map

The combination of evaluation results with tsunami scenario by Mardiatno (2008) and Muhari et all (2012) shows that some areas were allocated for settlements still potentially affected by tsunami. Under these conditions, the necessary efforts for tsunami disaster risk reduction can be done by using structural and non-structural mitigation. For structural mitigation purpose, the use of vegetation such as mangroves and casuarina are more recommended than using wall/dike (Mardiatno, Djati, 2008); (Mardiatno, D., 2013); (Muhari, A., et all, 2012). In addition, at certain locations can be set up vertical evacuation shelter. Complementing these structural mitigation measures, the implementation of non-structural mitigation measures should also be done through an intensive and ongoing socialization. Socialization should be done on a regular basis. It is one important effort for strengthening community preparedness in facing the threat of tsunami disaster in the future.

\section{CONCLUSIONS AND SUGGESTIONS}

Based on the description that has been presented in the previous section, it can be concluded that tsunami risk in Pacitan experienced a significant change in areas with high tsunami hazard class. It is caused by the potential increase of settlements. This condition is a consequence of the increase in the number of households nearly doubled, so that the allocation of space for residential areas had been increased. The growth of settlements is directed both to good and moderate land suitability and also by considering the potential threat of tsunami.

\section{ACKNOWLEDGMENT}

The research was funded by the Faculty of Geography, through the scheme "Bantuan Pendanaan Perguruan Tinggi Berbadan Hukum" Universitas Gadjah Mada Fiscal Year 2016. The author wishes to thank to all persons who have supported in collecting data and writing the manuscript. 


\section{REFERENCES}

[1] Baja, Sumbangan, 2012, "Perencanaan Tata Guna Lahan dalam Pengembangan Wilayah: Pendekatan Spasial dan Aplikasinya", Yogyakarta, Penerbit ANDI.

[2] Brinkman, R, dan A.J. Smith, 1973, "Land Evaluation for Rural Purpose", Summary of an expert consultation, Wageningen, The Netherlands, 6-12.

[3] Cinacher, A.J dan Conacher, J, 2000, "Environmental Planning and Management in Australia", Oxford University Press: Melbourne.

[4] FAO, 1976, "A Framework for Land Evaluation", FAO Soils Bull no 32, Food and Agriculture Organization of the United Nations, Rome.

[5] Hardjowigeno, S. dan Widiatmaka, 2007, "Kesesuaian Lahan dan Perencanaan Tataguna Tanah", Yogyakarta, Gadjah Mada University Press.

[6] Harspool,N., Pranantyo, I., Griffin, J., Latief, H., Natawidjaja, D.H., Kongko, W., Cipta, A., Bustaman, B., Anugrah, S.D., Thio, H.K, 2014, "A probabilistik tsunami hazard assessment for Indonesia", Nat Hazard Earth Syst Sci, 14, 3105-3122.

[7] Lassey, W.R, 1997, "Planning in Rural Environment", McGraw-Hill New York

[8] Mardiatno, Djati, 2008, "Tsunami Risk Assessement Using ScenarioBased Aproach, Geomorphological Analysis and Geographic Information System: A Case Study in South Coastal Areas of Java Island-Indonesia", Dissertasion, Faculty of Geo- and Atmospheric Sciences of the University of Innsbruck.

[9] Mardiatno, D., 2013, “A proposal for tsunami mitigation by using coastal vegetations: some findings from southern coastal area of Central Java", Indonesia, Journal of Natural Resources and Development, 07, 85-95 (DOI 10.5027/jnrd.v3i0.07).

[10] Muhari, A., Mueck, M., Diposaptono, S., dan Spahn, H., 2012, "Tsunami Mitigation Planning in Pacitan, Indonesia: A Review of Existing Efforts and Ways Ahead, Science of Tsunami Hazards", Vol 31/4, 244-267.

[11] Mudin, Yudam; Pramana, W.J., Sabhan., 2015, "Pemetaan Tingkat Risiko Bencana Tsunami Berbasis Spasial di Kota Palu”, Gravitasi, Vol 14, No.2

[12] Muta'ali, Lutfi., 2015, "Teknik Analisis Regional untuk Perencanaan Wilayah, Tata Ruang dan Lingkungan”, Yogyakarta: Badan Penerbit Fakultas Geografi (BPFG) Universitas Gadjah Mada.

[13] Pawlukiewicz, Michael, Prema Katari Gupta, and Carl Koelbel., 2007, "Ten Principles for Coastal Development", Washington, D.C.: ULI-the Urban Land Institute.

[14] Strunz, G., Post, J., Zosseder, K., Wegscheider, S., Mück, M., Riedlinger, T., Mehl, H., Dech, S., Birkmann, J., Gebert, N., Harjono, H., Anwar, H. Z., Sumaryono, Khomarudin, R. M., and Muhari, A., "Tsunami risk assessment in Indonesia", Nat. Hazards Earth Syst. Sci., $11,67-8$.

[15] Taubenbock, H., Goseberg, N., Lymmel, G., Setiadi, N., Schlurmann, T., Nagel, K., Siegert, F., Birkmann, J., Traub, K.-P., Dech, S., Keuck, V., Lehmann, F., Strunz, G., and Klopfel, H., "Risk reduction at the Last-Mile: an attempt to turn science into action by the example of Padang, Indonesia", Nat. Hazards, 65, 915-945.

[16] United Nations International Strategy for Disaster R'eduction (UNISDR), 2009, "Terminology on Disaster Risk Reduction", Geneva, Switzerland: UNISDR 